\section{Shaping the multifunctional tree: the use of Salicaceae in environmental restoration}

\author{
Roberto Tognetti, Claudia Cocozza, Marco Marchetti
}

Poplars and willows (and other fast growing tree species) form an important component of agroforestry systems, providing a wide range of ecosystem services and products. The workshop held in Capracotta $\left(6^{\text {th }}\right.$ and $7^{\text {th }}$ June 2012) has communicated the latest research on poplars and willows in the field of environmental restoration conducted in Italy, providing a condensed overview on their basic response to pollutants and use in environmental monitoring, highlighting future challenges of phytotechnology issues. In the frame of the project MIUR-PRIN 2008 "Molecular, physiological, and agronomic analyses for selecting and managing Salicacee in phytoremediation", 17 talks were delivered to an audience of more than 50 researchers. Prominence was given to stress biology and the importance of poplar and willow breeding in meeting the needs of ecological restoration. The aim of this review is provide a timely account of the questions related to phytotechnology in shaping the multifunctional tree, particularly with regard to tree responses to environmental pollution. While the question is scientifically challenging, progress may be achieved by exposing the different environmental restoration models and underlying guiding principles to tests against experimental data and each other. Research and development should focus simultaneously on maximizing the yield of multipurpose tree plantations, while preserving or restoring ecosystem services of close-tonature willow-poplar stands (e.g., riparian forests). We hope that this review will stimulate further studies in this interesting area of tree biology.

Keywords: Agroforestry Systems, Climate Change, Phytoremediation, Poplar, Restoration Ecology, Willow

\section{Introduction}

Biomass currently represents approximately $14 \%$ of the world's final energy consumption (Parikka 2004). About 25\% of the usage is in industrialized countries, where a significant level of investment in environmental protection has been made to meet emission standards. The remaining $75 \%$ of primary energy use of biomass is in heat production for household energy needs of developing countries and in process heat production for biomass-based industries through the use of their generated residues. Renew-

$\square$ Dipartimento di Bioscienze e Territorio, Università degli Studi del Molise, c.da Fonte Lappone, I-86090 Pesche (IS - Italy)

@ Roberto Tognetti (tognetti@unimol.it)

Received: Nov 21, 2012 - Accepted: Dec 19, 2012

Citation: Tognetti R, Cocozza C, Marchetti $M, 2013$. Shaping the multifunctional tree: the use of Salicaceae in environmental restoration. iforest 6: 37-47 [online 201301-21] URL: http://www.sisef.it/iforest/ contents?id=ifor0920-006

Communicated by: Marco Borghetti productivity of agroecosystems (Evett et al. 2011, Zalesny et al. 2011). Indeed, large regions of the Mediterranean's southern rim are subjected to a decline of fertility due to the increasing degradation of soils, loss of organic matter, and pollution of water resources. In Mediterranean countries, multifunctional tree crop plantations might be conveniently used for bioenergy as well as for shade, windbreaks, mulch and phytoremediation.

The practice of growing tree crops on short rotations (less than 15 years) in high density plantations to produce lignocellulosic feedstock for the pulp, board and/or energy industries is acknowledged in the literature by a variety of terms (Mitchell et al. 1999). These appellations, for example "energy forestry" or "short rotation forestry", are useful to separate such practices from the traditional forestry with a stand development of many decades until the final harvest. These multipurpose cultivations have a long tradition in Europe, tracing back to the Middle Age (Burschel \& Huss 1987). For instance, willow coppice has been widespread for different implementations, as e.g., the production of baskets, and poplars have been used for paper production during the last centuries. More recently, the emphasis of growing these plantations has been stressed to the production of woody biomass for energy using fast-growing broadleaved trees, such as poplars, willows, eucalyptus (e.g., Mughini et al. 2011), etc. (depending on their geographic and climatic suitability), as an alternative to fossil fuels, with further technical and economical benefits, since the deep and dense rhizosphere of Salicaceae may enhance the ability by homogenously exploring large soil volumes for extraction and degradation of contaminants and by providing lands for bioenergy productions unusable for agro-food purposes.

High-density plantations of fast-growing tree species may enrich landscape by increasing structural and biological diversity in open agricultural landscapes (Brockerhoff et al. 2008). Multipurpose tree crops can serve as tools for the amelioration of environmental problems at the local scale, in ecological restoration and land reclamation plans, and even at the global level, as carbon sink plantations. The disparate information on environmental remediation and ecological services of tree plantations on arable or marginal land should be synthesized to implement site-specific remediation strategies. Remediation strategies include: wastewater treatment, organic waste recycling and riparian buffer zones, and contamination management of heavy metals, organic chemicals and hydrocarbons (e.g., Bianconi et al. 2011, Guidi et al. 2012). It must be pointed out that cultivation methods of tree crops are 
Fig. 1 - Research network of participants at the workshop: major pollutants and experimental approach.

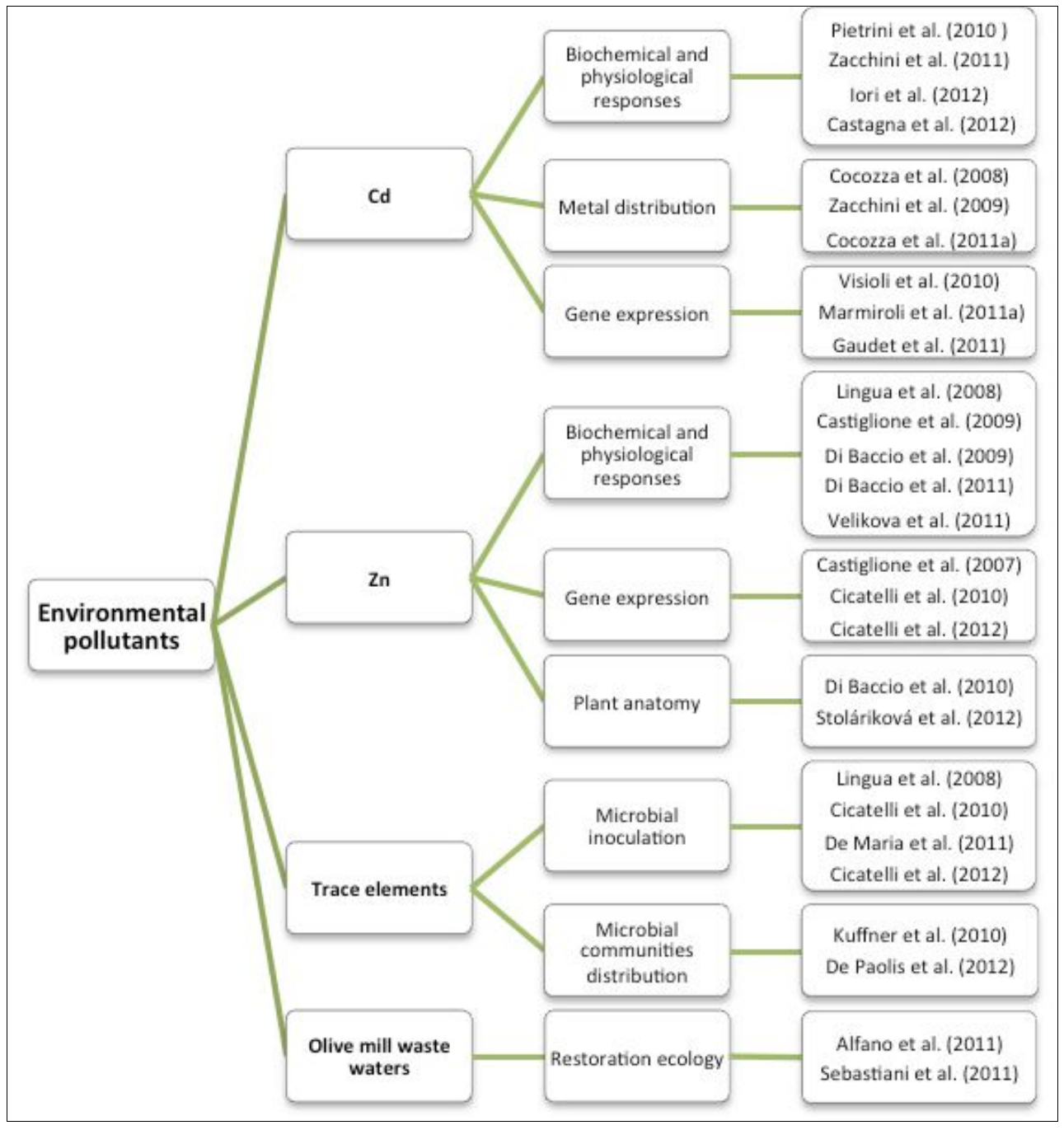

closer to agricultural practices than forestry due to their management intensity, which usually implies nutrient inputs in the form of fertilization and water irrigation, at least in warmer climates. This would imply more research to investigate whether specific management practices of multifunctional tree plantations can influence the sustainability of the bio-energy chain from an environmental and financial point of view.

A project was funded by the Italian Ministry of Education and Research (MIUR), National Interest Research Program (PRIN) 2008, on "Molecular, physiological, and agronomic analysis for selecting and managing Salicaceae in phytoremediation" (following PRIN 2005 "Trees and forest plantations for environmental restoration: physiological and molecular mechanisms in the selection of Salicaceae for phytoremediation of heavy metals and hydrocarbons"). The project has had the main task of providing national and local stakeholders with updated information on biomass production and phytoremediation activity of multifunctional tree crop plantations. With respect to the final event concluding the project, about 50 researchers were actually registered denoting a rather complex research network (Fig. 1, Fig. 2 ) in contributing to a long-term collaborative national repository, where experiments on innovative techniques and their applications can be discussed.

The theme of the workshop, "Stress biology in Salicaceae: research models towards multifunctional plantations", was chosen in view of the increasing imperative that local communities face in developing low-carbon, bio-based economies and livelihoods. The workshop brought together researchers in the climate change mitigation and environmental monitoring potential of poplar and willow (and eucalypts) plantations. Ranging from the lab to the field scale, this workshop summarized the current knowledge and gaps in the stress biology of these Salicaceae and their impacts on the environment (environmental monitoring, ecological restoration, carbon sequestration) at national level, crafting guidelines for land reclamation.

Several scientific presentations in the workshop reported positive effects on the en- vironment, including carbon sequestration and ecological restoration benefits, at the field scale, with impacts strongly depending on the management, age, size and heterogeneity of the biomass plantations. However, at the regional scale, significant uncertainties on environmental effects of bioenergy tree plantations still exist, and there is a major concern that extensive commercial production of bioenergy plantations could have negative consequences on biodiversity, particularly in areas of high nature-conservation value.

\section{Response of Salicaceae to pollutants and monitoring of the changing landscape}

Methods with a good potential for coping with environmental pollutions are emerging from phytoremediation experiments with Salicaceae. Specific amendments (application of certain chemicals, mostly chelating agents, to the soil significantly enhances metal accumulation by plants) and/or selected plants (based on the identification of "useful genetic diversity" associated with 


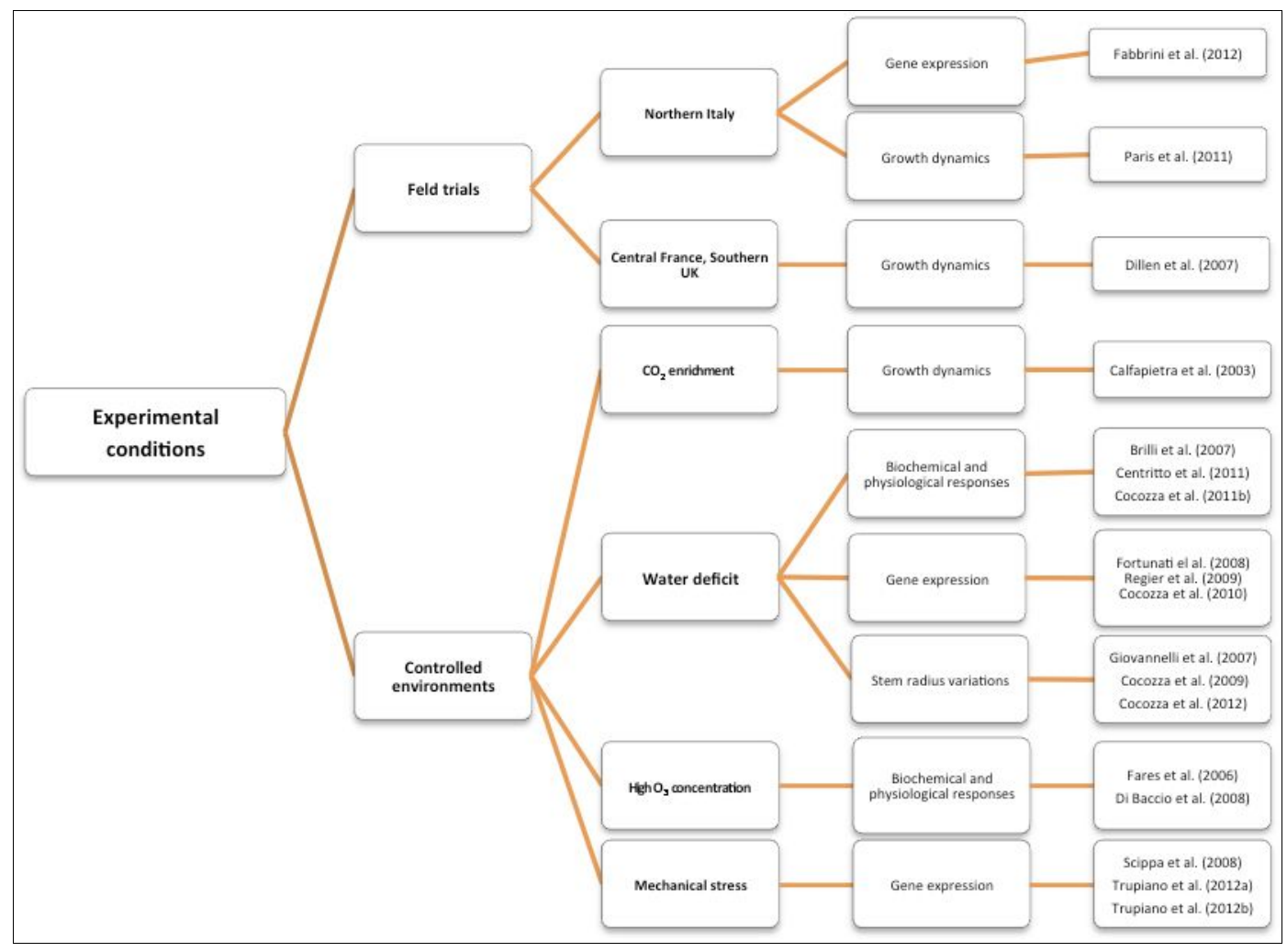

Fig. 2 - Research network of participants at the workshop: experimental conditions and research aims.

growth, physiological and biochemical traits) have been proposed as an alternative for the cleaning up of metal polluted soils (Marmiroli et al. 2011a). In several investigations, researchers have sought for plant systems reasonably efficient in extracting heavy metals from soil or water, or in cometabolizing organics with autochthonous or inoculated bacteria in the rhizospheres (Marmiroli et al. 2011a). Nevertheless, despite intensive research over the past decades, the real potential of phytoremediation has not been fully clarified due to the scarcity of field trials (Van Nevel et al. 2007). These are essential to identify the complex set of sitespecific interactions between soil, plant, pollutant(s) (Castiglione et al. 2009) and soil microbial populations (Cicatelli et al. 2012).

The characterization of Salicaceae, driven by small genome, easiness of agamic propagation, genetic susceptibility to transformation and the availability of genetic maps and genomic resources (Taylor 2002, Cronk 2005, Tuskan et al. 2006) appears promising for selecting candidates for phytoremediation. In Italy, metals uptake capacity and tolerance in poplar clones have been extensively investigated (Di Baccio et al. 2003, Sebastiani et al. 2004, Castiglione et al. 2007, Lingua et al. 2008, Zacchini et al. 2009). The choice of varying plant genotypes and research protocols allows testing clone adaptation ability to specific growth conditions (e.g., Guidi \& Labrecque 2010). Clone-specific functional and structural mechanisms have been found to play a role in tolerating and counteracting heavy metals excess in many species, such as the storage in relatively old tissues, differential accumulation and distribution capacity in leaf and root cells, restriction in uptake and/or transport, modification of leaf structure, causing impairments in plant growth processes (e.g., Di Baccio et al. 2009). On the other hand, the distribution of pollutants at the root level and within the root profile has shown differential accumulation patterns between species and clones of Salicaceae (Cocozza et al. 2008, Cocozza et al. 2011a).

In roots, the capacity to bind heavy metals, such as $\mathrm{Cu}$ and $\mathrm{Zn}$, in the cell wall has a protective action against the deleterious effect of metals by reducing the amounts of cytosolic metal, and representing plant suitability for phytostabilisation (Brunner et al. 2008). However, a limitation in ion binding specificity of $\mathrm{Cd}$ would result in increased metal accumulation in the root and decreased metal translocation to the shoot (e.g., Gussarsson et al. 1995), depending on the specific clone. On one hand, Stoláriková et al. (2012) in a specific poplar clone (I-214) exposed to excess of $\mathrm{Zn}$ found that the root did not develop the exodermis and the role of barrier for apoplasmic transport was fully assured by the endodermis. Casparian bands as well as suberin lamellae in endodermis developed closer to the root apex, and the endodermis played an efficient role as efficient barrier for transport of excess $\mathrm{Zn}$ from the outer parts to the stele of poplar roots (Stoláriková et al. 2012).
Exclusion strategy and internal detoxification are both important in metal tolerance. Clone-specific metal mobility through plant compartments may induce exclusion of metals in shoot tissue relative to soil concentrations in Salicaceae (e.g., Castiglione et al. 2009). Detoxification of heavy metals, especially non-essential heavy metals, is often attributed to post-translationally synthesized thiol-rich short metal binding proteins termed phytochelatins (Grill et al. 1985). The accumulation (Zacchini et al. 2009) and binding (Iori et al. 2012) of metals, as well as the protection of the integrity and functionality of physiological (Tognetti et al. 2004, Pietrini et al. 2010, Fernàndez et al. 2012) and metabolic processes (Pietrini et al. 2003, Di Baccio et al. 2010), might result by a restricted uptake and/or limited root-toshoot translocation. The metal might be recovered in the aerial parts (Castiglione et al. 2007). At leaf level, heavy metals can strongly alter leaf morphology and ultrastructure (Lingua et al. 2008, Castiglione et al. 2009), and negatively affect PSII activity, decreasing D1 and D2 reaction center proteins, but not light harvesting antenna system (LHCII) and protein expression (Todeschini et al. 2011). Iori et al. (2012) have observed that the high tolerance of a clone might be associated to the activity of antioxidative enzymes and the ability to increase thiol and phytochelatin concentrations in response to metal exposure.

The term phytoremediation also includes the use of plants associated with plant 
growth promoting bacteria (PGPB) and arbuscular mycorrhizal fungi (AMF - Gamalero et al. 2009). Microorganism activity involved in the phytoremediation process may increase the potential for metal mobilization and uptake (de Souza et al. 1999, Puttsepp et al. 2004, Kuffner et al. 2008, 2010, De Maria et al. 2011, De Paolis et al. 2011), colonizing the plant roots. Microorganism activity has been found to play a role in increasing both the plant biomass (Gamalero et al. 2009) and the protective action against pollutants (Cicatelli et al. 2010). The proteomic approach has been applied to depict changes in a specific pattern of protein expression (Lingua et al. 2012), such as the enhanced expression of metallothioneins (Cicatelli et al. 2012) and polyamines (Castiglione et al. 2009).

\section{Breeding for phytoremediation}

The domestication and breeding of improved hyperaccumulator species and the application of genetic engineering to develop fast growing high biomass plants with enhanced metal uptake, translocation and tolerance are needed (Barceló \& Poschenrieder 2003). In situations where available hyperaccumulator species are too small to afford sustainable clean-up procedures (in terms of time and productivity), biotechnology may be required to combine hyperaccumulation and high biomass production, as in the case of fast growing tree species. However, sitespecific adaptation of general strategies developed in basic scientific research programs can provide sustainable, environment friendly solutions for the cleanup of contaminated soils and sediments.

Because of long breeding cycles (a traditional breeding program requires $26+$ years for completion), tree domestication cannot be rapidly reached through traditional genetic improvement methods alone, whereas integrating modern genetic and genomic techniques with conventional breeding will process faster tree domestication. Indeed, programs that utilize advanced methods of breeding and propagation require approximately 13 years (Harfouche et al. 2012). The early identification using genomic selection prediction models will improve its efficiency by reducing the cycle of genetic improvement, without eliminating the field-testing phase, from mating to propagation of seeds for commercial plantation, to approximately 5 years.

The genus Populus results to be an excellent model for studying the evolution of gender determination because of the genuswide occurrence of dioecy-related genderdetermining systems that can provide new perspectives on the genetic mechanism of gender determination in plants in general (Tuskan et al. 2012, Tognetti 2012). The genetic control of important adaptive traits is still poorly understood in most forest trees species. In this sense, quantitative trait locus (QTL) mapping is a powerful approach to identify key genomic regions controlling adaptive traits (Frewen et al. 2000, Neale \& Ingvarsson 2008, Gailing et al. 2009), especially for species where a reference genome is already available (Tuskan et al. 2006). Fabbrini et al. (2012) have studied QTL mapping in poplars, focusing on traits tightly linked to environmental adaptation, such as bud set and bud flush.

Some genes with decreased expression may be functionally related to stress responses, as the case of salinity (Beritognolo et al. 2011), where the biological processes of gene set related to carbohydrate metabolism, energy metabolism and photosynthesis have been found to be in agreement with the strong inhibition of leaf functionality, showing genotype specificity. Gene pathways, such as glutathione metabolic pathways, might be involved in the different plant response, for instance, to Cd (Gaudet et al. 2011) and Zn excess (Di Baccio et al. 2005), as well as $\mathrm{O}_{3}$ sensitivity (Di Baccio et al. 2008).

The molecular genetic diversity approach can take advantage of single nucleotide polymorphisms (SNPs) in candidate genes in the search for diversity with functional consequences in relation to $\mathrm{Cd}$ exposure (Marmiroli et al. 2011b). Indeed, proteomic analyses in Populus spp. have identified a number of proteins and enzyme activities, which are either up- or down-regulated by exposure to different level of contamination with $\mathrm{Cd}$ (Visioli et al. 2010). Di Baccio et al. (2011) have identified functional gene sets, through a microarray-based comparative analysis, as differentially regulated in the leaves of clone I-214 subjected to an excess but sub-lethal dose of $\mathrm{Zn}$. The approach, together with novel high-throughput techniques for transcriptome analysis such as RNA sequencing (RNA-Seq), allows the identification and absolute expression detection of candidate genes for $\mathrm{Zn} /$ heavy metal tolerance in poplar species and hybrids characterized by natural remarkable genetic variability.

However, phenotypic plasticity and environmental adaptations from "trade-offs" between gene expression and environmental conditions would be difficult to quantify without protein analysis. In particular, proteins with altered synthesis due to changes in gene expression may be used to design molecular markers for the selection of genotypes (Kieffer et al. 2009, Regier et al. 2009, Visioli et al. 2010). However, Scippa et al. (2008) have studied the complex mechanism involved in the reaction of root biology to environmental stress. In particular, Trupiano et al. (2012a) have observed functional and structural changes in roots, which emitted new laterals and increased biomass and lignin synthesis under mechanical stress.
Furthermore, Trupiano et al. (2012b) have investigated proteins involved in the signal transduction pathway, detoxification and metabolism up regulated and/or down regulated in the bent root.

Therefore, comparative genomics of poplars subjected to stress conditions have generated resources useful for improving the annotation of genes and provided novel insights in the plant defense/tolerance mechanisms. These findings provide useful information on tree species adaptation to pollutants, as well as powerful tools for the selection of stress-tolerant poplar clones. In brief, enhancing phytoremediation efficiency warrants improvements in analytical tools, considering functional and structural traits to identify "useful genetic diversity" for genotype selection (Marmiroli et al. 2011a).

\section{Restoration ecology with fast growing trees}

Tree growth may help forests to take up large amounts of the emitted fossil fuels. Forest plantations, as carbon sinks, are playing a critical role in the climate change negotiations and constitute a central element in the scheme to limit atmospheric greenhouse gas concentrations set out by international agreements. Predicting future climates is uncertain, though temperatures are projected to rise by $1.5-3.5^{\circ} \mathrm{C}$ by the end of the century. A better mechanistic understanding of global warming consequences might come from an analysis of site-specific effects of temperature on growth and development of temperate and boreal tree species (Way \& Oren 2010).

Faster tree growth in a warmer climate may help mitigate $\mathrm{CO}_{2}$ release from fossil fuels and land-use change, especially where temperatures are limiting, though natural disturbances (extreme drought, insect outbreak, forest fires) may also increase under warmer temperature conditions, which may be detrimental to carbon storage from faster tree growth. The success of clonal testing and tree improvement in breeding programs for Salicaceae is currently advancing the trend towards multipurpose tree plantations for maximizing tree productivity, which may be implemented in decision support systems for plantation management (Fig. 3).

Plants are continuously subjected to the impact of combined consequences of climate change, such as rising temperature and intensifying drought or increasing tropospheric ozone and soil metal levels, and poplars have been found to establish a variety of defensive strategies involving the co-ordinated modulation of stress perception (Regier et al. 2009, Zacchini et al. 2009, Cocozza et al. 2010, Castagna et al. 2012). However, many aspects of the regulatory processes, which adjust gene expression to changes in the environmental conditions, are still unknown 


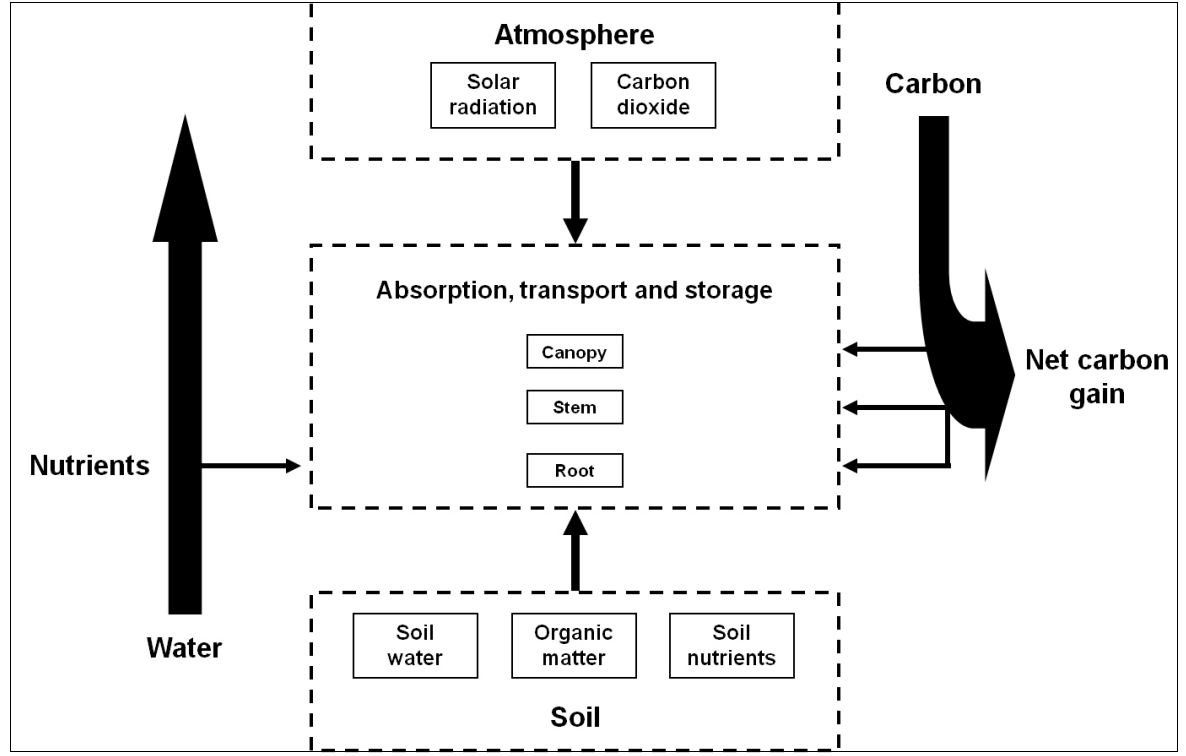

Fig. 3 - Net tree productivity as the difference between carbon acquired by photosynthesis and that used for construction and maintenance costs. The uptake of $\mathrm{CO}_{2}$ from the atmosphere is linked to the loss of water from the leaves, the root system and transport and storage tissues (water, carbohydrates, nutrients) being essential to support photosynthesis (e.g., Tognetti et al. 1999, Johnson et al. 2002). The atmosphere (sunlight and water demand) and the soil (water and nutrient supply) constitute the environmental forcing. Within these constraints, vegetation is assumed to optimize canopy, transport and storage tissues, roots, and stomata dynamically to maximize its net tree productivity, which may be functional to improve breeding and selection methodologies.

and completing the picture of the signaling networks represents a challenge for the upcoming years (Castagna \& Ranieri 2009).

Poplars subjected to severe and combined environmental constraints, such drought and high temperatures, reveal the overriding effects of drought on isoprene emission, pos sibly affecting protein level or substrate supply (Fortunati et al. 2008, Centritto et al. 2011). The maintenance of high levels of isoprene emission, contributed by an increasingly large fraction of the carbon fixed by photosynthesis, is an indirect evidence of the importance of isoprene in protecting poplars against abiotic stresses, such as water stress (e.g., Brilli et al. 2007), ozone stress (Fares et al. 2006) and Ni stress (Velikova et al. 2011). These findings are likely to be relevant for process-based models that account for stress effects in order to predict the emissions of isoprenoid in globally changing environmental conditions, as well as the sensitivity to high UV-A (Pallozzi et al. 2012), and to scale up the impact of isoprenoid on air chemistry and quality at regional and global levels (Brilli et al. 2007).

Pellegrino et al. (2011) have observed the important role of plant-soil interactions under different harvest intensity in sustainable bioenergy crop management, with improved soil quality in poplar plantations (short rotation forestry, SRF) in comparison with intensive cropping systems. The establishment of multiple willow rotations in short rotation coppice (SRC) has been found to contribute to the long-term enrichment of soil organic carbon (Lockwell et al. 2012). Massa et al. (2010) and Teodorescu et al. (2011) have shown that the establishment of willow for urban green structures, such as sound barriers, snow fences and wind breaks, along highways and streets could replace autochthonous trees, facing poor air quality, water and soil multi-metal pollution.

Poplar plantations established on abandoned farmland sites are an interesting application to remediate olive mill water (OMW) disposed in soils. Activities are in progress to assess the short- and long-term effects of repeated OMW field applications and the capability of SRF (poplar) to stabilize and biodegrade these compounds (Sebastiani et al. 2011). The suppressive effect of OMW composts (in terms of pathogens) seems to be due to the combined effects of suppression phenomena caused by the presence of microorganisms competing for both nutrients and space as well as by the activity of specific antagonistic microorganisms (Alfano et al. 2011). Di Bene et al. (2013) have suggested the use of OMW as organic amendment in agriculture, given the short-term negative effects on soil quality, which can be considered negligible after a suitable waiting period.

The application of manure to fertilize arable lands is one of the major means through which veterinary sulfonamides (SAs), that are widely used veterinary drugs to prevent animal diseases and to increase food conversion efficiency (Rooklidge 2004), enter the environment. The capacity of woody plants to phytoremediate this class of antibiotics is reported only in few studies. Preliminary results on the capacity of woody plants to phytoremediate this class of antibiotics have been obtained under laboratory conditions for Salix fragilis L., which was found to absorb and tolerate antibiotics, which affected tree growth and physiological processes, without dramatic consequences (Michelini et al. 2012). The phytoextraction of sulfonamides by willows can effectively limit their diffusion by erosion agents and their interaction with other living organisms.

\section{Research needs and future challenges of agroforestry plantations}

Agroforestry systems are essential to human well being, they supply the bulk of humanity's food and fiber, and cover a large portion of the Earth's land area. In southern Europe, the use of SRF plantations appears to offer a highly promising and politically desirable option among the range of renewable energy sources currently available ( $\mathrm{Di}$ Matteo et al. 2012). Even though, in Mediterranean areas, the climatic conditions and the anthropogenic pressure have led to an increasing menace of desertification with potentially catastrophic consequences for plant biodiversity, agricultural and forestry activities, and the whole environment. Thus, exchange competence and expertise is necessary in order to improve the understanding of how and to what extent the climate and its factors will affect, and in many cases will set a limit to, the primary process of plant life and in turn agricultural ecosystems (Centritto \& Loreto 2005). The main challenge of agroforestry plantations encompasses not only the traditional needs for sustainable wood production, but perhaps more importantly, the mitigation of today's environmental extremes of climate change and associated increases in soil and air temperatures, drought, frequency of pest attacks. The use of agroforestry crops is a promising tool for reducing atmospheric $\mathrm{CO}_{2}$ concentration through fossil fuel substitution. In particular, high yield SRF plantations are becoming popular worldwide for biomass production and their role is acknowledged in the Kyoto Protocol (Calfapietra et al. 2003).

While the contribution of SRF plantations to climate change mitigation is being investigated, the impact of climate change itself on growth and productivity of these plantations needs further research, since their management might need to be modified accordingly (Calfapietra et al. 2010). In Italy, traditional poplar cultivation, based on ten-year rotation for plywood production, spread over about 
70000 ha, mainly in the Po Valley, although other plantations exist that are oriented to different purposes (Vietto et al. 2007). Trials have been recently conducted in order to evaluate growth and yield of hybrid clones (e.g., Paris et al. 2011) and to define hydrological parameters of SRC (e.g., Guidi et al. 2008), obtaining preliminary indication of the productive cycle of the plantations that need to be strengthened to proper irrigation scheduling. Guidi et al. (2009) have found that changes of chemical composition in wood and bark are related to the increase of stem size, and at stand level, proportion of chemical compounds, useful in SRC to improve the quality of biomass for bioethanol conversion, denotes strong differences between rotations. On the other hand, Cocozza et al. (2011b) have evidenced how irrigation regime influences the wood anatomy and biochemistry of poplar clones, and how clone-specific responses may affect the proper selection of plant material and plantation site in relation to fluctuations in water availability during summer. If the area coverage and biomass productivity of these plantations is bound to increase further, due to concerted research and development efforts, specific clones and field trials are required.

The sustainable management of agroforestry plantations associated with policy instruments requires integration of carbon sequestration to allow multifunctional tree plantations achieving ecological restoration. These insights will enable us to disentangle environmental effects and phytoremediation strategies, and will allow shaping the multifunctional tree, with benefit for climate mitigation and land monitoring strategies (Fig. 4).

With the more recent advent of genome scale data (Brunner \& Nilsson 2004), plantation forestry combined with forest biotechnology and genetic engineering of trees is likely to become a major source for wood products and environmental services in the future (Fenning \& Gershenzon 2002). Currently a number of on-going research projects are exploring the possibilities to genetically modify poplars and willows for improving the productivity of trees by increasing their growth rates, altering wood quality and chemical parameters in desired ways for specific uses (e.g., to improve the cost efficiency of paper and pulp production), increasing their resistance to pests and herbicides, enhancing their tolerance of various kinds of abiotic stresses (e.g., extremes of climate change and associated increases in soil and air temperatures, drought frequency), controlling flowering and maturation, and optimizing their suitability for bio/phytoremediation of polluted land and water (Campbell et al. 2003). In this sense, the agroforestry research community is called upon to generate appropriate networks and investigating plantation service supply, through a range of ecosystem models and scenarios of climate and land-use change. The development and/or improvement of efficient protocols will be beneficial for the application of methods to different environmental fields. These will provide information to overcome socio-economic barriers for of poplar and willow (and other fast growing species) plantations, leading to new protocols and applications. This approach aims to establish long-term networking on multipurpose tree plantations (Fig. 5).

The promising prospects offered by gene technologies, especially for tree breeding, have promoted their use in the forestry. wild forests and plantations can represent a threat to their integrity (Hoenicka et al. 2012). Forest breeding programs need to evaluate the potentials of molecular techniques to provide fast growing clones for multipurpose plantation forestry within a short timespan. For risk assessment it is important to look at all processes involved in transgene outcrossing (Bialozyt 2012). The choice of plant species for remediation will greatly influence which ecological partners (including bacteria, fungi, other plants, animals) and interactions will be present at the site, and consequently the fate of the pollutant. The remediation processes may affect positively or negatively ecological partners, thus influence trophic levels. While plantmicrobe consortia often work together in remediation of organic pollutants, as men- organize and coordinate initiatives for economic and environmental sustainability However, ecological boundaries between

tioned above, much still remains to be discovered about the nature of the interactions and the molecular mechanisms involved (e.g., signal molecules, genes induced). Overall, relatively little is known at this point about the ecological effects of the use of plants in phytoremediation (e.g., the effect of metal accumulation on specialist herbivores, and the mobilization of toxic elements into food webs). Transgenic plants may also influence these ecological relationships. Potentially, the escape of transgenic plants or genes could result in a competitive advantage under local conditions, which warrants further studies on plant materials and management practices that minimize risks (PilonSmits \& Freeman 2006).

The success of intensive poplar cultivation is partly due to the great versatility of its wood and its properties of lightness, clear color, homogeneity, and ease of working (peeling, bonding, and finishing), but also to the normally very fast growth of the species on flood plains and fertile soils. The high wood production of poplars is strictly linked to soil water availability, which is normally assured by irrigation in intensive upland plantations with recurrent soil water deficit. However, clones capacity to restore stem growth after drought might influence the wood quality in poplar (Giovannelli et al. 2007), as annual rings with different wood properties may be produced under recurrent drought conditions (Cocozza et al. 2011b). Instantaneous and seasonal responses to environmental stimuli are often used as selection criteria in breeding programmes (Dillen et al. 2007). For instance, Cocozza et al.

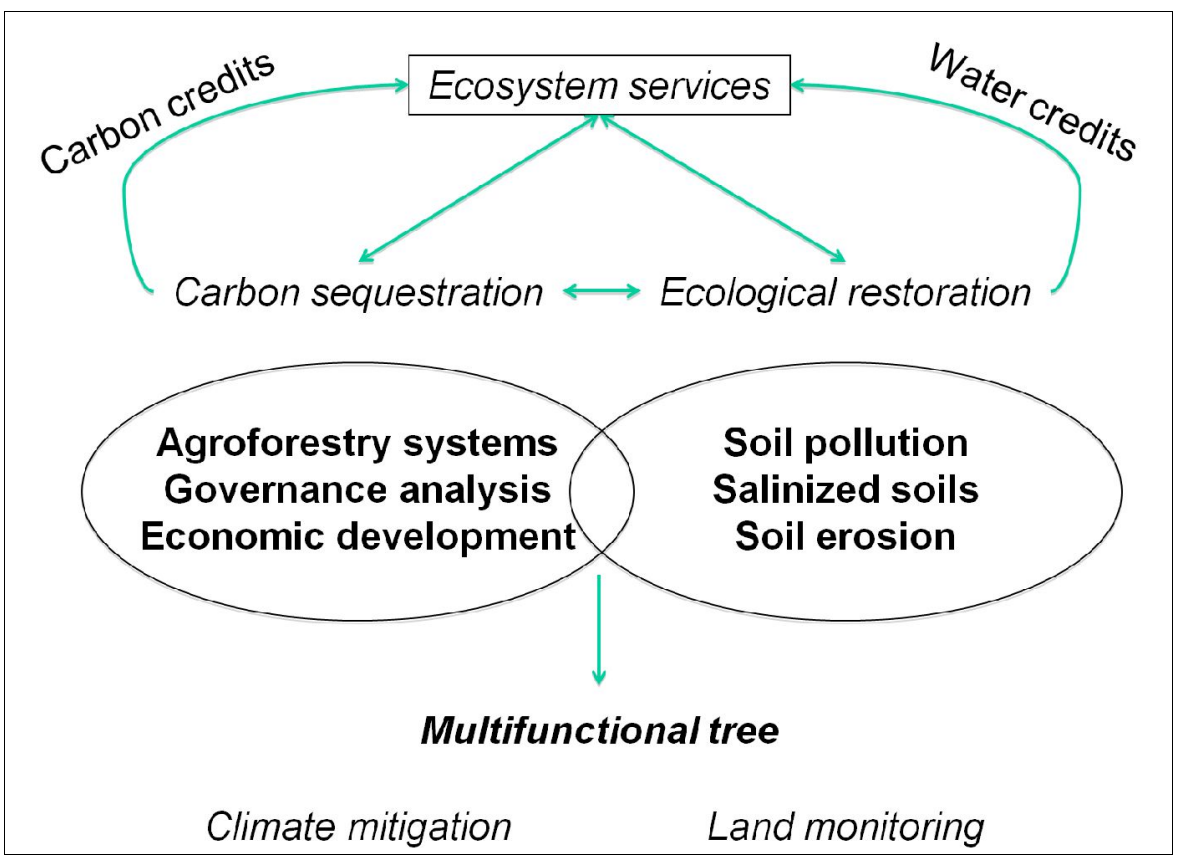

Fig. 4 - Balancing agroforestry systems to sustainable management associated with policy instruments requires integration of carbon sequestration - ecological restoration relationships of tree plantations at various scales of environmental problems. 


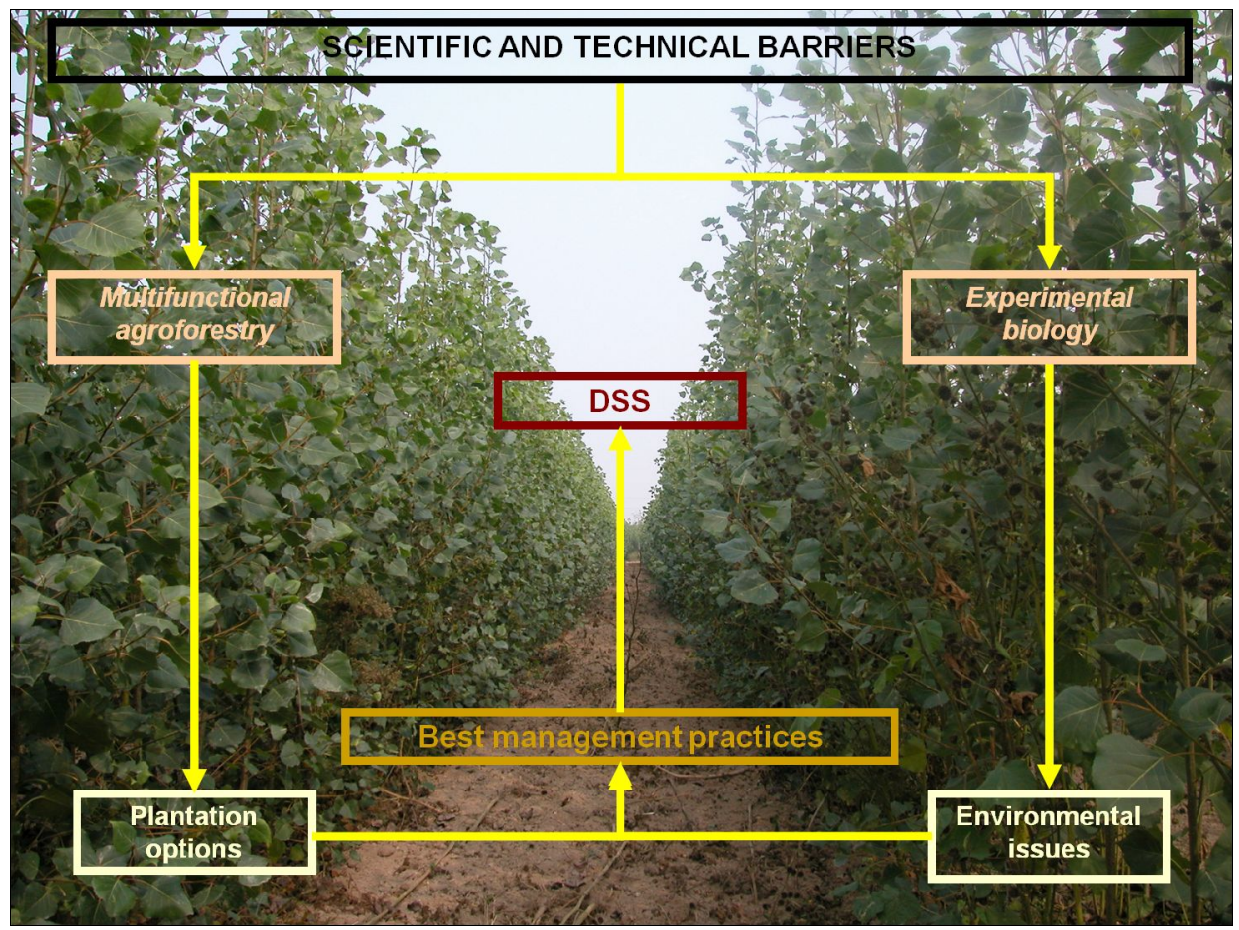

Fig. 5 - Different action needs may be identified, dealing with the technical and biological aspects inherent to plantation forestry and environmental restoration, as well as with socio-economic implications. To this end, a decision support system (DSS) can be developed and applied to multipurpose tree plantations.

(2009) have highlighted a clone-specific sensitivity of woody tissues and the pattern of phenological aspects related to environmental conditions through the variation in rate and duration of daily stem shrinkage in response to low air temperature in winter Future research are needed to focus on the relationships between radial growth fluxes and wood technological properties in Salicaceae.

So far, the evidence is that SRC (willow and poplar) may be a suitable system for decontaminating soil with slightly elevated concentrations of $\mathrm{Cd}$, such as in agricultura land resulting from high rates of application of phosphate fertilizers (Pulford \& Watson 2003 ) in a relatively short-term period. Similar evidence is not available for other elements, with estimates of hundreds, or even thousands, of years being required to clean up soil contaminated with elements such as $\mathrm{Pb}$ and $\mathrm{Zn}$. Well-designed and well-documented demonstration projects are needed to promote phytoremediation as a remediation technique, especially if budgets of local authorities are limited and the alternative is that no treatment is carried out. In choosing the optimal strategy for multifunctional tree plantations, it may be preferable to grow specialized tree crops with high yield, as the greenhouse gas value increases, leaving more land to the recolonization of native woody species (cf. Anderson-Teixeira et al. 2012), including poplar-willow alluvial stands. Alternatively, multifunctional tree plantations with high ecosystem service may be widely cultivated or restored for the replacement of ecologically degraded functions (e.g., biodiversity conservation), inten- tionally sacrificing maximum yield. This debate over the relative advantages of land sharing $v$ s. land sparing takes on a new urgency in the face of expanding bioenergy needs.

Marmiroli et al. (2011a) have suggested a new approach to reach a satisfactory method to selection of plants for phytoremediation performance, that can be obtained with genetic and molecular tools to identify markers associated with growth parameters, physiological and biochemical traits. The challenge of contamination clean up and the crucial contribution of research can be put into perspective by considering some statistic and economic data. The time factor is by far the most critical point in plant-based clean-up techniques. However, the long persistence of heavy metal contamination in soils (residence times of thousands of years) makes even long term cleaning strategies attractive. The potential of transgenic plants to efficiently clean up of contaminated sites may help to change adverse public opinion. Nonetheless, future research should address not only the "know-how" of producing efficient plants for phytoremediation and their integration into sustainable cropping and management systems, but should also clarify the potential impact of transgenic plants on the target habitat and the fate of the introduced genes in the surrounding environment (Barceló \& Poschenrieder 2003).

\section{Conclusion}

The research community is called to harmonize the outcomes of the large number of experimental results on multifunctional tree plantations (with particular reference to pop- lar, willow and eucalypts) in order to identify the most useful targeted plant traits in the perspective of global change scenarios (Tognetti et al. 2011). This review focuses on recent literature produced mostly by Italian research teams involved in investigation of the tools, factors, processes and technologies required for the throughput characterization of Salicaceae. Here we report on the application and the development of new and rapid approaches for quantifying variation in wood and/or tree-specific anatomical, morphological, physiological and molecular traits. How to promote the sustainable development of multipurpose tree plantations is still a matter of debate. The development of alternatives to traditional fossil-based fuels for power, the reversion of farmlands into natural forest areas, the rehabilitation of degraded sites, the re-establishment of forests in fluvial areas have all become common goals for central and regional government agencies at the European level. However, the success of plantation programs will depend on appropriate genetic resources availability, relative benefits and costs of plantation, as well as on effective research, development and management, innovation and technological advances. The realization of multipurpose tree plantations will also be contingent increasingly on recognition of and respect for the principle of sustainability, in its full sense.

The advancement of knowledge and the removal of constraints, facilitating the applicability of environmental biotechnologies to remove and monitor the diffusion of pollutants, have progressed enormously, although there are still a number of gaps to be filled 
in. Government incentives for renewable energy or positive trend in pricing for raw materials could encourage farmers to develop the biomass supply chain (with non-food tree crops) in the short term. These encouragements could be justified by increasing the opportunities for rural economic development, while implementing environmental benefits, such as alternative to fossil fuel, carbon sink, and positive impact on biodiversity in comparison with traditional food crops.

On the other hand, transgenic poplars and willows may provide the means to effectively remediate sites contaminated with a variety of pollutants at much faster rates and at lower costs than can be achieved with current conventional techniques (Doty et al. 2007). Indeed, the success and future development of multipurpose tree plantation is largely dependent upon the selection of appropriate candidate genotypes possessing the most desirable and exploitable growth characteristics, physiology, morphology and adaptability to agronomic practices. Yet, a successful path toward increased production of biomass-derived energy requires a thorough accounting of costs and benefits (Georgescu et al. 2011).

An important workshop output was towards combining data and models to provide a support to decisions. A common challenge of this research network is the design of a plant ideotype, implementing the identification of descriptors of performance, but also of economic and ecological factors related to the ecosystem services, and the risk linked to the cultivation of plants for environmental restoration. Considering all factors, from the biological features to the environmental conditions, from the constraints of legislation to the considerations of economy, the definition of criteria for choosing a plant ideotype would enable operators to select the most suitable plant for each task.

The application of system biology may combine information from different research fields, producing a complex network of genes, proteins and functions that link phenotypes to genotypes and to molecular mechanisms. Research on system biology may lead to the identification of novel genes and their use in developing transgenic plants with specific remediation capacities, to the comprehension of the effect of the remediation processes on the ecological interactions and, and to the mobilization of the pollutant into the ecosystems. Likewise, data must be integrated with risk assessment and evaluation of ecosystem services, such as those provided by natural alluvial stands of Salicaceae. Designing a plant ideotype for environmental restoration in different contexts will provide additional benefits, including pollution mitigation, biomass and biofuels availability, $\mathrm{CO}_{2}$ storage, microclimate regulation, biodiversity shelter, and contribute to improve landscape management in urban setting.

\section{Acknowledgements}

We acknowledge the Project "Molecular, physiological, and agronomic analyses for selecting and managing Salicacee in phytoremediation" (MIUR, PRIN 2008) for financial support. We also thank all participants in the Workshop on "Biologia degli stress in Salicaceae: modelli di ricerca propedeutici a piantagioni multifunzionali" (Capracotta, Italy, 6-7 June 2012). The contributions were summed-up by the President of the Italian Society of Silviculture and Forest Ecology (SISEF), Prof. Piermaria Corona. Special thanks go to staff and board members of the "Giardino della Flora Appenninica di Capracotta", in particular the Curator Dr. Giovanni Pelino.

\section{References}

Alfano G, Lustrato G, Lima G, Vitullo D, Ranalli G (2011). Characterization of composted olive mill wastes to predict potential plant disease suppressiveness. Biological Control 58: 199-207. doi: 10.1016/j.biocontrol.2011.05.001

Anderson-Teixeira KJ, Duval BD, Long SP, Delucia EH (2012). Biofuels on the landscape: is "land sharing" preferable to "land sparing"? Ecological Applications 22 (8): 2035-2048. - doi: 10.1890/12-0711.1

Barceló J, Poschenrieder C (2003). Phytoremediation: principles and perspectives. Contributions to Science 2: 333-344. [online] URL: http://publicacions.iec.cat/repository/pdf/00000022/00000 097.pdf

Beritognolo I, Harfouche A, Brilli F, Prosperini G, Gaudet M, Brosché M, Salani F, Kuzminsky E, Auvinen P, Paulin L, Kangasjärvi J, Loreto F, Valentini R, Scarascia Mugnozza G, Sabatti M (2011). Comparative study of transcriptional and physiological responses to salinity stress in two contrasting Populus alba L. genotypes. Tree Physiology 31: 1335-1355. - doi: 10.1093/treephys/tpr083

Bialozyt R (2012). Gene flow in poplar - experiments, analysis and modelling to prevent transgene outcrossing. iForest 5: 147-152. - doi: 10.3832/ifor0618-005

Bianconi D, De Paolis MR, Agnello MC,Lippi D, Pietrini F, Zacchini M, Polcaro C, Donati E, Paris P, Spina S, Massacci A (2011). Field-scale rhyzoremediation of a contaminated soil with hexachlorocyclohexane $(\mathrm{HCH})$ isomers: the potential of poplars for environmental restoration In: "Phytoremediation: processes, characteristics, and applications". Hauppauge, Nova Science Publisher, New York, USA.

Bowyer C, Baldock D, Kretschmer B, Polakova J (2012). The GHG emissions intensity of bioenergy: does bioenergy have a role to play in reducing Europe's GHG emissions? Institute for European Environmental Policy (IEEP), London, UK.

Brilli F, Barta C, Fortunati A, Lerdau M, Loreto F,
Centritto M (2007). Response of isoprene emission and carbon metabolism to drought in white poplar (Populus alba) saplings. New Phytologist 175: 244-254. - doi: 10.1111/j.1469-8137.2007. 02094.x

Brockerhoff EG, Jactel H, Parrotta JA, Quine CP, Sayer J (2008). Plantation forests and biodiversity: oxymoron or opportunity? Biodiversity and Conservation 17: 925-951. - doi: 10.1007/ s10531-008-9380-x

Brunner AM, Nilsson O (2004). Revisiting tree maturation and floral initiation in the poplar functional genomics era. New Phytologist 164: 43-51. - doi: 10.1111/j.1469-8137.2004.01165.x Brunner I, Luster J, Günthardt-Goerg MS, Frey B (2008). Heavy metal accumulation and phytostabilisation potential of tree fine roots in a contaminated soil. Environmental Pollution 152: 559568. - doi: 10.1016/j.envpol.2007.07.006

Burschel P, Huss J (1987). Grundi $\beta$ des Waldbaus. Parey, Hamburg, Germany, pp. 352.

Calfapietra C, Gielen B, Galema ANJ, Lukac M, De Angelis P, Moscatelli MC, Ceulemans R, Scarascia-Mugnozza G (2003). Free-air $\mathrm{CO}_{2}$ enrichment (FACE) enhances biomass production in a short-rotation poplar plantation. Tree Physiology 23: 805-814. - doi: 10.1093/treephys/ 23.12.805

Calfapietra C, Gielen B, Karnosky D, Ceulemans R, Scarascia Mugnozza G (2010). Response and potential of agroforestry crops under global change. Environmental Pollution 158: 1095 1104. - doi: 10.1016/j.envpol.2009.09.008

Campbell MM, Brunner AM, Jones HM, Strauss SH (2003). Forestry's fertile crescent: the application of biotechnology to forest trees. Plant Biotechnology Journal 1: 141-154. - doi: 10.1046/j. 1467-7652.2003.00020.x

Castagna A, Baccio D, Tognetti R, Ranieri A, Sebastiani L (2012). Differential ozone sensitivity interferes with cadmium stress in poplar clones. Biologia Plantarum. - doi: 10.1007/s10535-0120274-0

Castagna A, Ranieri A (2009). Detoxification and repair process of ozone injury: From $\mathrm{O}_{3}$ uptake to gene expression adjustment. Environmental Pollution 157: 1461-1469. - doi: 10.1016/j.envpol. 2008.09.029

Castiglione S, Franchin C, Fossati T, Lingua G, Torrigiani P, Biondi S (2007). High zinc concentrations reduce rooting capacity and alter metallothionein gene expression in white poplar $(\mathrm{Po}-$ pulus alba L. cv. Villafranca). Chemosphere 67 (6): 1117-1126. - doi: 10.1016/j.chemosphere. 2006.11.039

Castiglione S, Todeschini V, Franchin C, Torrigiani P, Gastaldi D, Cicatelli A, Rinaudo C, Berta G, Biondi S, Lingua G (2009). Clonal differences in survival capacity, copper and zinc accumulation, and correlation with leaf polyamine levels in poplar: A large-scale field trial on heavily polluted soil. Environmental Pollution 157: 2108-2117. - doi: 10.1016/j.envpol.2009.02.011 Centritto M, Brilli F, Fodale R, Loreto F (2011). Different sensitivity of isoprene emission, respiration and photosynthesis to high growth tempe- 
rature coupled with drought stress in black poplar (Populus nigra) saplings. Tree Physiology 31: 275-286. - doi: 10.1093/treephys/tpq112

Centritto M, Loreto F (2005). Photosynthesis in a changing world: photosynthesis and abiotic stresses. Agriculture, Ecosystems and Environment 106: 115-117. - doi: 10.1016/j.agee.2004 10.001

Cicatelli A, Lingua G, Todeschini V, Biondi S, Torrigiani P, Castiglione S (2010). Arbuscular mycorrhizal fungi restore normal growth in a white poplar clone grown on heavy metal-contaminated soil, and this is associated with upregulation of foliar metallothionein and polyamine biosynthetic gene expression. Annals of Botany 106: 791-802. - doi: 10.1093/aob/mcq170

Cicatelli A, Lingua G, Todeschini V, Biondi S, Torrigiani P, Castiglione S (2012). Arbuscular mycorrhizal fungi modulate the leaf transcriptome of a Populus alba L. clone grown on a zinc and copper-contaminated soil. Environmental and Experimental Botany 75: 25-35. - doi 10.1016/j.envexpbot.2011.08.012

Cocozza C, Minnocci A, Tognetti R, Iori V, Zacchini M, Scarascia Mugnozza G (2008). Distribution and concentration of cadmium in root tissue of Populus determined by scanning electron microscopy and energy-dispersive $\mathrm{x}$-ray $\mathrm{mi}$ croanalysis. iForest 1: 96-103. - doi: 10.3832/ ifor0458-0010096

Cocozza C, Lasserre B, Giovannelli A, Castro G, Fragnelli G, Tognetti R (2009). Low temperature induces different cold sensitivity in two poplar clones (Populus $x$ canadensis Mönch "I-214" and P. deltoides Marsh. "Dvina"). Journal of Experimental Botany 60: 3655-3664. - doi: 10.1093 jjxb/erp212

Cocozza C, Cherubini P, Regier N, Saurer M, Frey B, Tognetti R (2010). Early effects of water deficit on two parental clones of Populus nigra grown under different environmental conditions. Functional Plant Biology 37: 244-254. - doi 10.1071/FP09156

Cocozza C, Maiuro L, Tognetti R (2011a). Mapping Cadmium distribution in roots of Salicaceae through scanning electron microscopy with $\mathrm{x}$-ray microanalysis. iForest 4: 113-120. - doi: 10.3832 /ifor0563-004

Cocozza C, Giovannelli A, Traversi ML, Castro G, Cherubini P, Tognetti R (2011b). Do tree-ring traits reflect different water deficit responses in young poplar clones (Populus $x$ canadensis Mönch "I-214" and P. deltoides "Dvina")? Trees 25: 975-985. - doi: 10.1007/s00468-011-0572-8

Cocozza C, Giovannelli A, Lasserre B, Cantini C, Lombardi F, Tognetti R (2012). A novel mathematical procedure to interpret the stem radius variation in olive trees. Agricultural and Forest Meteorology 161: 80-93. - doi: 10.1016/j.agrformet.2012.03.016

Cronk QCB (2005). Plant eco-devo: the potential of poplar as a model organism. New Phytologist 166: 39-48. - doi: 10.1111/j.1469-8137.2005. 01369.x

De Maria S, Rivelli AR, Kuffner M, Sessitsch A, Wenzel WW, Gorfer M, Strauss J, Puschenreiter
M (2011). Interactions between accumulation of trace elements and macronutrients in Salix caprea after inoculation with rhizosphere microorganisms. Chemosphere 84: 1256-1261. doi: 10.1016/j.chemosphere.2011.05.002 de Souza MP, Chu D, Zhao M, Zayed AM, Ruzin SE, Schichnes D, Terry N (1999). Rhizosphere bacteria enhance selenium accumulation and volatilization by indian mustard. Plant Physiology 119: 565-574. - doi: 10.1104/pp.119.2.565

Deckmyn G, Muys B, Garcia Quijano J, Ceulemans R (2004). Carbon sequestration following afforestation of agricultural soils: comparing oak/beech forest to short-rotation poplar coppice combining a process and a carbon accounting model. Global Change Biology 10: 1482-1491. doi: 10.1111/j.1365-2486.2004.00832.x

De Paolis MR, Pietrosanti L, Capotorti G, Massacci A, Lippi D (2011). Salicaceae establishment in a heavy metal-contaminated site revealed by eco-physiological characterization of the culturable soil bacterial fraction. Water Air and Soil Pollution 216: 505-512. - doi: 10.1007/ s11270-010-0548-0

Di Baccio D, Tognetti R, Sebastiani L, Vitagliano C (2003). Responses of Populus deltoides $\mathrm{x}$ Populus nigra (Populus $x$ euramericana) clone I-214 to high zinc concentrations. New Phytologist 159: 443-452. - doi: 10.1046/j.1469-8137. 2003.00818.x

Di Baccio D, Kopriva S, Sebastiani L, Rennenberg H (2005). Does glutathione metabolism have a role in the defence of poplar against zinc excess? New Phytologist 167: 73-80. - doi: 10.1111/j.1469-8137.2005.01462.x

Di Baccio D, Castagna A, Paoletti E, Sebastiani L, Ranieri A (2008). Could the differences in $\mathrm{O}_{3}$ sensitivity between two poplar clones be related to a difference in antioxidant defense and secondary metabolic response to $\mathrm{O}_{3}$ influx? Tree Physiology 28: 1761-1772. - doi: 10.1093/treephys/28.12.1761

Di Baccio D, Tognetti R, Minnocci A, Sebastiani L (2009). Responses of the Populus $\times$ euramericana clone I-214 to excess zinc: Carbon assimilation, structural modifications, metal distribution and cellular localization. Environmental and Experimental Botany 67: 153-163. - doi: 10. 1016/j.envexpbot.2009.05.014

Di Baccio D, Minnocci A, Sebastiani L (2010). Leaf structural modifications in Populus $x$ euramericana subjected to $\mathrm{Zn}$ excess. Biologia Plantarum 54: 502-508. - doi: 10.1007/s10535010-0088-x

Di Baccio D, Galla G, Bracci T, Andreucci A, Barcaccia G, Tognetti R, Sebastiani L (2011). Transcriptome analyses of Populus $\times$ euramericana clone I-214 leaves exposed to excess zinc. Tree Physiology 31: 1293-1308. - doi: 10.1093/ treephys/tpr106

Di Bene C, Pellegrino E, Debolini M, Silvestri N, Bonari E (2013). Short- and long-term effects of olive mill wastewater land spreading on soil chemical and biological properties. Soil Biology and Biochemistry 56: 21-30. - doi: 10.1016/ j.soilbio.2012.02.019
Dillen SY, Marron N, Bastien C, Ricciotti L, Salani F, Sabatti M, Pinel MPC, Rae AM, Taylor G, Ceulemans R (2007). Effects of environment and progeny on biomass estimations of five hybrid poplar families grown at three contrasting sites across Europe. Forest Ecology and Management 252: 12-23. - doi: 10.1016/j.foreco.2007. 06.003

Di Matteo G, Sperandio GG, Verani S (2012). Field performance of poplar for bioenergy in southern Europe after two coppicing rotations: effects of clone and planting density. iForest 5 : 224-229. - doi: 10.3832/ifor0628-005

Doty SL, James CA, Moore AL et al. (2007). Enhanced phytoremediation of volatile environmental pollutants with transgenic trees. Proceedings of the National Academy of Sciences USA 104: 16816-16821. - doi: 10.1073/pnas.0703276 104

Evett SR, Zalesny RS Jr, Kandil NF, Stanturf JA, Soriano C (2011). Opportunities for woody crop production using treated wastewater in Egypt. II. Irrigation strategies. International Journal of Phytoremediation 13: 122-139. - doi: 10.1080/ 15226514.2011.568548

Fabbrini F, Gaudet M, Bastien C, Zaina G, Harfouche A, Beritognolo I, Marron N, Morgante M, Scarascia-Mugnozza G, Sabatti M (2012). Phenotypic plasticity, QTL mapping and genomic characterization of bud set in black poplar. Plant Biology 3: 12-47. - doi: 10.1186/1471-2229-1247

Fares S, Barta C, Brilli F, Centritto M, Ederli L, Ferranti F, Pasqualini S, Reale L, Tricoli D, Loreto F (2006). Impact of high ozone on isoprene emission, photosynthesis and histology of developing Populus alba leaves directly or indirectly exposed to the pollutant. Physiologia Plantarum 128: 456-465. - doi: 10.1111/j.13993054.2006.00750.x

Fenning TM, Gershenzon J (2002). Where will the wood come from? Plantation forests and the role of biotechnology. Trends in Biotechnology 20: 291-296. - doi: 10.1016/S0167-7799(02)019832

Fernàndez J, Zacchini M, Fleck I (2012). Photosynthetic and growth responses of Populus clones Eridano and I-214 submitted to elevated $\mathrm{Zn}$ concentrations. Journal of Geochemical Exploration 123: 77-86. - doi: 10.1016/j.gexplo. 2012.01.010

Fischer G, Prieler S, van Velthuizen H (2005). Biomass potentials of miscanthus, willow and poplar: results and policy implications for Eastern Europe, Northern and Central Asia. Biomass and Bioenergy 28: 119-132. - doi: 10.1016/j.biombioe.2004.08.013

Fortunati A, Barta C, Brilli F, Centritto M, Zimmer I, Schnitzler J-P, Loreto F (2008). Isoprene emission is not temperature-dependent during and after severe drought-stress: a physiological and biochemical analysis. The Plant Journal 55: 687-697. - doi: 10.1111/j.1365-313X.2008. 03538. $\mathrm{x}$

Frewen BE, Chen THH, Howe GT, Davis J, Rohde A, Boerjan W, Bradshaw HD Jr (2000). 
Quantitative trait loci and candidate gene mapping of bud set and bud flush in Populus. Genetics 154: 837-845. [online] URL: http://www. ncbi.nlm.nih.gov/pubmed/10655234

Gailing O, Vornam B, Leinemann L, Finkeldey R (2009). Genetic and genomic approaches to assess adaptive genetic variation in plants: forest trees as a model. Physiologia Plantarum 137: 509-519. - doi: 10.1111/j.1399-3054.2009.012 $63 . x$

Gamalero E, Lingua G, Berta G, Glick BR (2009). Beneficial role of plant growth promoting bacteria and arbuscular mycorrhizal fungi on plant responses to heavy metal stress. Canadian Journal of Microbiology 55: 501-14. - doi: 10.1139/ W09-010

Gaudet M, Pietrini F, Beritognolo I, Iori V, Zacchini M, Massacci A, Scarascia Mugnozza G, Sabatti M (2011). Intraspecific variation of physiological and molecular response to cadmium stress in Populus nigra L. Tree Physiology 31: 1309-1318. - doi: 10.1093/treephys/tpr088

Georgescu M, Lobell DB, Field CB (2011). Direct climate effects of perennial bioenergy crops in the United States. Proceedings of the National Academy of Sciences USA 108: 4307-4312. doi: 10.1073/pnas.1008779108

Giovannelli A, Deslauriers A, Fragnelli G, Scaletti L, Castro G, Rossi S, Crivellaro A (2007). Evaluation of drought response of two poplar clones (Populus x canadensis Mönch "I-214" and P. deltoides Marsh. "Dvina") through high resolution analysis of stem growth. Journal of Experimental Botany 58: 2673-2683. - doi: 10.1093/ jxb/erm 117

Grill E, Winnacker EL, Zenk MH (1985). Phytochelatins: the principal heavy-metal complexing peptides of higher plants. Science 230: 674-676. - doi: 10.1126/science.230.4726.674 Guidi W, Kadri H, Labrecque M (2012). Establishment techniques to using willow for phytoremediation on a former oil refinery in southern Quebec: achievements and constraints. Chemistry and Ecology 28: 49-64. - doi: 10.1080/0275 7540.2011 .627857

Guidi W, Labrecque M (2010). Effects of high water supply on growth, water use, and nutrient allocation in willow and poplar grown in a 1-year pot trial. Water Air and Soil Pollution 207: 85101. - doi: 10.1007/s11270-009-0121-X

Guidi W, Piccioni E, Bonari E (2008). Evapotranspiration and crop coefficient of poplar and willow short-rotation coppice used as vegetation filter. Bioresource Tecnhology 99: 4832-4840. doi: 10.1016/j.biortech.2007.09.055

Guidi W, Tozzini C, Bonari E (2009). Estimation of chemical traits in poplar short-rotation coppice at stand level. Biomass and Bioenergy 33: 1703-1709. - doi: 10.1016/j.biombioe.2009.09. 004

Gussarsson M, Adalsteinsson S, Jensén R, Asp H (1995). Cadmium and copper interactions on the accumulation and distribution of $\mathrm{Cd}$ and $\mathrm{Cu}$ in birch (Betula pendula Roth) seedlings. Plant and Soil 171: 185-187. - doi: 10.1007/BF00009585 Harfouche A, Meilan R, Kirst M, Morgante M,
Boerjan W, Sabatti M, Scarascia Mugnozza G (2012). Accelerating the domestication of forest trees in a changing world. Trends in Plant Science 17: 64-72. - doi: 10.1016/j.tplants.2011.11. 005

Hoenicka H, Lehnhardt D, Polak O, Fladung M (2012). Early flowering and genetic containment studies in transgenic poplar. iForest 5: 138-146. doi: 10.3832/ifor0621-005

Johnson JD, Tognetti R, Paris P (2002). Water relations and gas exchange in poplar and willow under water stress and elevated atmospheric $\mathrm{CO}_{2}$. Physiologia Plantarum 115: 93-100. - doi: 10.1034/j.1399-3054.2002.1150111.x

Iori V, Pietrini F, Massacci A, Zacchini M (2012). Induction of metal binding compounds and antioxidative defence in callus cultures of two black poplar ( $P$. nigra) clones with different tolerance to cadmium. Plant Cell, Tissue and Organ Culture 108: 17-26. - doi: 10.1007/s11240-0110006-8

Kieffer P, Planchon S, Oufir M, Ziebel J, Dommes J, Hoffmann L, Hausman JF, Renaut J (2009). Combining proteomics and metabolite analyses to unravel cadmium stress-response in poplar leaves. Journal of Proteome Research 8: 400417. - doi: 10.1021/pr800561r

Kuffner M, Puschenreiter M, Wieshammer G, Gorfer M, Sessitsch A (2008). Rhizosphere bacteria affect growth and metal uptake of heavy metal accumulating willows. Plant and Soil 304: 35-44. - doi: 10.1007/s11104-007-9517-9

Kuffner M, De Maria S, Puschenreiter M, Fallmann K, Wieshammer G, Gorfer M, Strauss J, Rivelli AR, Sessitsch A (2010). Culturable bacteria from $\mathrm{Zn}$ - and Cd-accumulating Salix caprea with differential effects on plant growth and heavy metal availability. Journal of Applied Microbiology 108: 1471-1484. - doi: 10.1111/j. 1365-2672.2010.04670.x

Lingua G, Franchin C, Todeschini V, Castiglione S, Biondi S, Burlando B, Parravicini V, Torrigiani P, Berta G (2008). Arbuscular mycorrhizal fungi differentially affect the response to high zinc concentrations of two registered poplar clones. Environmental Pollution 153: 147-157. doi: 10.1016/j.envpol.2007.07.012

Lingua G, Bona E, Todeschini V, Cattaneo C, Marsano F, Berta G, Cavaletto M (2012). Effects of heavy metals and arbuscular mycorrhiza on the leaf proteome of a selected poplar alone: a time course analysis. PLoS ONE 7: e38662. doi: 10.1371/journal.pone.0038662

Lockwell J, Guidi W, Labrecque M (2012). Soil carbon sequestration potential of willows in short-rotation coppice established on abandoned farm lands. Plant and Soil 360: 299-318. - doi: 10.1007/s11104-012-1251-2

Marmiroli M, Pietrini F, Maestri E, Zacchini M, Marmiroli N, Massacci A (2011a). Growth, physiological and molecular traits in Salicaceae trees investigated for phytoremediation of heavy metals and organics. Tree Physiology 31: 13191334. - doi: 10.1093/treephys/tpr090

Marmiroli M, Visioli G, Maestri E, Marmiroli N (2011b). Correlating SNP genotype with the phenotypic response to exposure to cadmium in Populus spp. Environmental Science and Technology 45: 4497-4505. - doi: 10.1021/es103708k Massa N, Andreucci F, Poli M, Aceto M, Barbato R, Berta G (2010). Screening for heavy metal accumulators amongst autochtonous plants in a polluted site in Italy. Ecotoxicology and Environmental Safety 73: 1988-1997. - doi: 10.1016/ j.ecoenv.2010.08.032

Michelini L, Meggio F, La Rocca N, Ferro S, Ghisi R (2012). Accumulation and effects of sulfadimethoxine in Salix fragilis L. plants: a preliminary study to phytoremediation purposes. International Journal of Phytoremediation 14: 388-402. - doi: 10.1080/15226514.2011.620654 Mitchell CP, Stevens EA, Watters MP (1999). Short-rotation forestry - operations, productivity and costs based on experience gained in the UK. Forest Ecology and Management 121: 123-136. doi: 10.1016/S0378-1127(98)00561-1

Mughini G, Alianiello F, Benedetti A, Mughini Gras L, Gras MA (2011). Clonal variation in arsenic, cadmium, chromium, copper, lead and zinc uptake by epigeous tissues of hybrid Eucalyptus clones used for biomass production. In: Proceedings of the "V European Bioremediation Conference". Chania (Greece) 4-7 July 2011.

Nassi O, Di Nasso N, Guidi W, Ragaglini G, Tozzini C, Bonari E (2010). Biomass production and energy balance of a 12-year-old short-rotation coppice poplar stand under different cutting cycles. Global Change Biology Bioenergy 2: 8997. - doi: 10.1111/j.1757-1707.2010.01043.x

Neale DB, Ingvarsson PK (2008). Population, quantitative and comparative genomics of adaptation in forest trees. Current Opinion in Plant Biology 11: 149-155. - doi: 10.1016/j.pbi.2007. 12.004

Pallozzi E, Fortunati A, Marino G, Loreto F, Agati G, Centritto M (2012). BVOC emission from Populus $\times$ canadensis saplings in response to acute UV-A radiation. Physiologia Plantarum. doi: 10.1111/j.1399-3054.2012.01687.x Parikka M (2004). Global biomass fuel resources. Biomass and Bioenergy 27: 613-620. - doi: 10.1016/j.biombioe.2003.07.005

Paris P, Mareschi L, Sabatti M, Pisanelli A, Ecosse A, Nardin F, Scarascia-Mugnozza G (2011). Comparing hybrid Populus clones for SRF across northern Italy after two biennial rotations: Survival, growth and yield. Biomass and Bioenergy 35: 1524-1532. - doi: 10.1016/j.biombioe.2010.12.050

Pellegrino E, Di Bene C, Tozzini C, Bonari E (2011). Impact on soil quality of a 10-year-old short-rotation coppice poplar stand compared with intensive agricultural and uncultivated systems in a Mediterranean area. Agriculture, Ecosystems and Environment 140: 245-254. - doi: 10.1016/j.agee.2010.12.011

Pietrini F, Iannelli MA, Pasqualini S, Massacci A (2003). Interaction of cadmium with glutathione and photosynthesis in developing leaves and chloroplasts of Phragmites australis (Cav.) Trin. ex strudel. Plant Physiology 133: 829-837. - doi: 10.1104/pp.103.026518 
Pietrini F, Zacchini M, Iori V, Pietrosanti L, Ferretti M, Massacci A (2010). Spatial distribution of cadmium in leaves and its impact on photosynthesis: examples of different strategies in willow and poplar clones. Plant Biology 12: 355363. - doi: 10.1111/j.1438-8677.2009.00258.x

Pilon-Smits EAH, Freeman JL (2006). Environmental cleanup using plants: biotechnological advances and ecological considerations. Frontiers in Ecology and the Environment 4: 203210. - doi: 10.1890/1540-9295(2006)004[0203: ECUPBA]2.0.CO;2

Pulford ID, Watson C (2003). Phytoremediation of heavy metal-contaminated land by trees'a review. Environment International 29: 529-540. doi: 10.1016/S0160-4120(02)00152-6

Puttsepp U, Rosling A, Taylor AFS (2004). Ectomycorrhizal fungal communities associated with Salix viminalis $\mathrm{L}$. and $S$. dasyclados Wimm. clones in a short rotation forestry plantation. Forest Ecology and Management 196: 413-424. doi: 10.1016/j.foreco.2004.04.003

Regier N, Streb S, Cocozza C, Schaub M, Cherubini P, Zeeman SC, Frey B (2009). Drought tolerance of two black poplar (Populus nigra L.) clones: contribution of carbohydrates and oxidative stress defence. Plant, Cell and Environment 32: 1724-1736. - doi: 10.1111/j.1365-3040. 2009.02030.x

Rooklidge SJ (2004). Environmental antimicrobial contamination from terraccumulation and diffuse pollution pathways. Science of the Total Environment 325: 1-13. - doi: 10.1016/j.scitot env.2003.11.007

Scippa GS, Trupiano D, Rocco M, Di Iorio A, Chiatante D (2008). Unraveling the response of poplar (Populus nigra) roots to mechanical stress imposed by bending. Plant Biosystems 142: 401413. - doi: 10.1080/11263500802151058

Sebastiani L, Scebba F, Tognetti R (2004). Heavy metal accumulation and growth responses in poplar clones Eridano (Populus deltoides x maximowiczii) and $\mathrm{I}-214$ (P. x euramericana) exposed to industrial waste. Environmental and $\mathrm{Ex}$ perimental Botany 52: 79-88. - doi: 10.1016/ j.envexpbot.2004.01.003

Sebastiani L, Di Baccio D, Minnocci A, Tognetti R, Segal E, Celano G (2011). Land application of olive oil mill waste water in a poplar plantation: initial site characterization. Acta Horticulturae 888: 345-352.

Stoláriková M, Vaculík M, Lux A, Di Baccio D, Minnocci A, Andreucci A, Sebastiani L (2012). Anatomical differences of poplar (Populus $\mathrm{x}$ euramericana clone I-214) roots exposed to zinc excess. Biologia 67: 483-489. - doi: 10.2478/ s11756-012-0039-4

Taylor G (2002). Populus: Arabidopsis for forestry. Do you need a model tree? Annals of Botany 90: 681-689. - doi: 10.1093/aob/mcf255

Teodorescu TI, Guidi W, Labrecque M (2011). The use of non-dormant rods as planting material: a new approach to establishing willow for environmental applications. Ecological Engineering 37: 1430-1433. - doi: 10.1016/j.ecoleng. 2011.03.031

Todeschini V, Lingua G, D'Agostino G, Carniato F, Roccotiello E, Berta G (2011). Effects of high zinc concentration on poplar leaves: a morphological and biochemical study. Environmental and Experimental Botany 71: 50-56. - doi: 10.1016/ j.envexpbot.2010.10.018

Tognetti R, Longobucco A, Raschi A, Miglietta F, Fumagalli I (1999). Responses of two Populus clones to elevated atmospheric $\mathrm{CO}_{2}$ concentration in the field. Annals of Forest Science 56: 493-500. - doi: 10.1051/forest:19990606

Tognetti R, Sebastiani L, Minnocci A (2004). Gas exchange and foliage characteristics of two poplar clones in soil amended with industrial waste. Tree Physiology 24: 75-82. - doi: 10.1093/treephys/24.1.75

Tognetti R, Massacci A, Scarascia Mugnozza G (2011). Fifth International Poplar Symposium: "Poplars and willows: from research models to multipurpose trees for a bio-based society". Tree Physiology 31: 1289-1292. - doi: 10.1093/treephys/tpr 117

Tognetti R (2012). Adaptation to climate change of dioecious plants: does gender balance matter? Tree Physiology 32: 1321-1324. - doi: 10.1093/ treephys/tps 105

Trupiano D, Di Iorio A, Montagnoli A, Lasserre B, Rocco M, Grosso A, Scaloni A, Marra M, Chiatante D, Scippa GS (2012a). Involvement of lignin and hormones in the response of woody poplar taproots to mechanical stress. Physiologia Plantarum 146: 39-52. - doi: 10.1111/j.13993054.2012.01601.x

Trupiano D, Rocco M, Renzone G, Scaloni A, Viscosi V, Chiatante D, Scippa GS (2012b). The proteome of Populus nigra woody root: response to bending. Annals of Botany 110: 415-432. doi: 10.1093/aob/mcs040

Tuskan GA, DiFazio S, Faivre-Rampant P, Gaudet M, Harfouche A, Jorge V, Labbé JL, Ranjan P, Sabatti M, Slavov G, Street N, Tschaplinski TJ, Yin T (2012). The obscure events contributing to the evolution of an incipient sex chromosome in Populus: a retrospective working hypothesis. Tree Genetics and Genomes 8: 559-571. doi: 10.1007/s11295-012-0495-6
Tuskan GA, DiFazio S, Jansson S et al. (2006). The genome of black cottonwood, Populus trichocarpa (Torr. \& Gray). Science 313: 15961604. - doi: 10.1126/science. 1128691

Van Nevel L, Mertens J, Oorts K, Verheyen K (2007). Phytoextraction of metals from soils: how far from practice? Environmental Pollution 150: 34-40. - doi: 10.1016/j.envpol.2007.05.024 Velikova V, Tsonev T, Loreto $\mathrm{F}$, Centritto $\mathrm{M}$ (2011). Changes in photosynthesis, mesophyll conductance to $\mathrm{CO}_{2}$, and isoprenoid emissions in Populus nigra plants exposed to excess nickel. Environmental Pollution 159: 1058-1066. - doi: 10.1016/j.envpol.2010.10.032

Vietto L, Chiarabaglio PM, Nervo G (2007). Environmental applications of poplar and willow germplasm in Italy: experiences and trends. In: Proocedings of the workshop "Environmental Applications of Poplar and Willow". Working Party, International Poplar Commission. Montreal (Quebec - Canada) 5-8 June 2007.

Visioli G, Marmiroli M, Marmiroli N (2010). Two-dimensional liquid chromatography technique coupled with mass spectrometry analysis to compare the proteomic response to cadmium stress in plants. Journal of Biomedicine and Biotechnology 2010 (4): 1-11. - doi: 10.1155/2010/ 567510

Way DA, Oren R (2010). Differential responses to changes in growth temperature between trees from different functional groups and biomes: a review and synthesis of data. Tree Physiology 30: 669-688. - doi: 10.1093/treephys/tpq015

Weih M (2004). Intensive short rotation forestry in boreal climates: present and future perspectives. Canadian Journal of Forest Research 34: 1369-1378. - doi: 10.1139/x04-090

Zacchini M, Pietrini F, Scarascia Mugnozza G, Iori V, Pietrosanti L, Massacci A (2009). Metal tolerance, accumulation and translocation in poplar and willow clones treated with cadmium in hydroponics. Water Air and Soil Pollution 197: 23- 34. - doi: 10.1007/s11270-008-9788-7

Zacchini M, Iori V, Scarascia Mugnozza G, Pietrini F, Massacci A (2011). Cadmium accumulation and tolerance in Populus nigra and Salix alba. Biologia Plantarum 55: 383-386. - doi: 10.1007/s10535-011-0060-4

Zalesny RS, Stanturf JA, Evett SR, Kandil NF, Sorianos C (2011). Opportunities for woody crop production using treated wastewater in Egypt. I. Afforestation strategies. International Journal of Phytoremediation 13: 102-21 - doi: 10.1080/ 15226514.2011.568539 